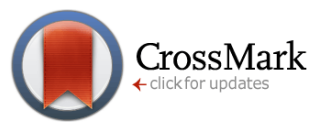

*For correspondence:

pvphuc@hcmuns.edu.vn

Competing interests: The authors declare that no competing interests exist.

Received: 15 September 2016

Accepted: 15 October 2016

Published: 29 October 2016

Copyright The Author(s) 2016. This article is published with open access by BioMedPress (BMP).

This article is distributed under the terms of the Creative Commons Attribution License (CC-BY 4.0) which permits any use, distribution, and reproduction in any medium, provided the original author(s) and the source are credited.

\section{Stem cell drugs: the next generation of pharmaceutical products}

\author{
Phuc Van Pham iD \\ Laboratory of Stem Cell Research and Application, University of Science, Vietnam \\ National University, Ho Chi Minh city, Viet Nam
}

\begin{abstract}
Stem cells represent a new treatment option in medicine and pharmacy. Stem cells have been increasingly used for the treatment of many diseases. In fact, they have spurred a new age of medicine called regenerative medicine. In recent years, regenerative medicine has become a new revolution in disease treatment, especially with the use of stem cell drugs. Stem cell drugs refer to live stem cell based products that used as drugs for particular diseases. Unlike autologous stem cell transplantation, stem cell drugs are "off-the-shelf" products that are ready to be used without requirement of any further manipulation. This review aims to summarize some of the approved stem cell drugs, and discuss the revolution of regenerative medicine and personalized medicine. As well, the review will discuss how stem cell drugs have led to a new direction in stem cell therapy, providing a new platform for patient needs.
\end{abstract}

\section{Keywords}

Stem cells, Stem cell drug, Pharmaceutical, Stem cell therapy, Stem Cell transplantation, hematopoietic stem cell, mesenchymal stem cell, HLA matching

\section{Introduction}

Stem cells are considered as the origin of the growth and development of human beings. The capability and relative of stem cell isolation, proliferation and modification gave rise to the field of stem cell application for disease treatment. Today, there is a huge potential benefit for the use of stem cells in disease treatment (stem cell therapy). To date, there are more than 100 different diseases that have been treated with stem cell transplantation. The first application of hematopoietic stem cells (HSCs) in 1950s by Donald et al. showed that stem cells could be used as drugs to treat diseases (Appelbaum 2007). 
Clinical applications of HSCs rapidly increased with more and more diseases treated with HSCs. From 1970s to 2000s, all HSC transplantations (HSCTs) were indicated for hematologic malignancies. In recent years, HSCTs have also been used in solid tumor treatment (Kotloff et al., 2004; Rodenhuis et al., 2003; Tallman et al., 2003).

Human leukocyte antigen ( $H L A)$ matching is an important component for successful HSCT (Lee et al., 2007; Petersdorf et al., 1998; Sasazuki et al., 1998). Therefore, in the initial years of HSCT, almost all cases were performed as autologous transplantation of HSCs. The stem cells were collected from bone marrow, umbilical cord blood or peripheral blood. However, autologous HSCT had some limitations, especially with regard to the quality and quantity of HSCs. More importantly, autologous HSCs have some mutations in their genome which limit their use in treating genetic diseases. To overcome these limitations, allogenic HSCT was suggested as a better platform; the use of selected HSC samples with greater quality and quantity can be controlled. In light of the demand for allogeneic HSCT, stem cell banks have been developed in several countries, such US, Japan, Korea, England and Germany (Armson et al., 2015). With greater characterization of HSCs (including HLA typing), stem cells were able to be commercialized as pharmaceutical products for transplantation in the US, beginning in the 2000s. Ducord and HemaCord are two HSC drugs introduced around 2010 in the US. However, since the HLA matching ratio is very low in the human population (about 1/100,000), the business of HSC drugs has only slowly developed.

From 2012 till now, stem cell drugs have advanced with mesenchymal stem cell (MSC) based products. Similar to HSCs, in the first clinical applications of MSCs, the MSCs were administered as autologous transplantation. Indeed, HLA matching as well as immune rejection are taken into consideration before transplantation. Some allogenic transplantations of MSCs have used immunosuppressive drugs to prevent or reduce the immune rejection of grafted cells in the host. However, increasing studies have confirmed that MSCs exhibit strong immune modulation capacity that can regulate the host's immune system; as well, they exhibit low immunogenicity compared to HSCs and other cells (Ankrum et al., 2014; Hoogduijn et al., 2010; P De Miguel et al., 2012; Rasmusson, 2006).

MSCs have been transplanted into patients without immune suppression and without HLA matching with safety (Hare et al., 2009; Karussis et al., 2010; Lalu et al., 2012; Wang et al., 2012). Based on such results, MSC based products have now been developed as drugs for patients with clear indications. The first MSC based stem cell drug was officially approved by the Food and Drug Agency of Canada in 2012. This drug was indicated to treat graft versus host disease (GVHD) related to HSCT. 
This review aims to summarize and discuss the development and growth of stem cell drugs in medicine and pharmacy. Stem cell drug has now become a new and potentially important member of regenerative medicine (Fig. 1).

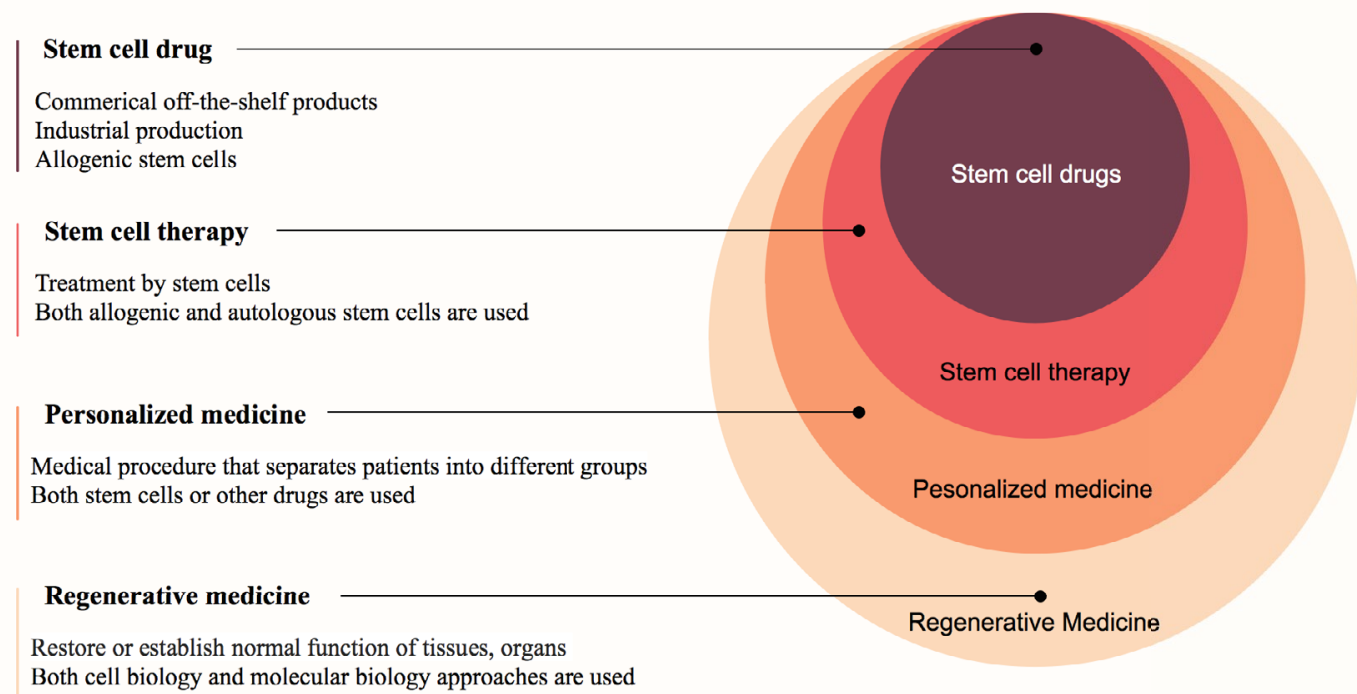

Figure 1. Stem cell drugs in regenerative medicine. Stem cell drugs are new members of stem cell therapy, personalized medicine and regenerative medicine. The development of stem cell drugs have impacted and advanced the stem cell industry as well as the pharmaceutical industry.

\section{What are stem cell drugs?}

A drug is defined as any substance other than food that when inhaled, injected, smoked, consumed, absorbed via a patch on the skin or dissolved under the tongue causes a physiological change in the body. In pharmacology, a drug (or pharmaceutical drug) is a substance used to treat, cure, prevent or diagnose a disease or to promote well-being. According to this definition, a drug must satisfy some criteria, such as having indication to treat any disease and is an offthe-shelf product. Therefore, by definition stem cell drugs are off-the-shelf products based on stem cells that are indicated to treat, cure, prevent or diagnose a disease or to promote well-being.

As off-the-shelf products, stem cell drugs are used in the allogeneic setting in stem cell transplantation. There are key differences between allogenic stem cell transplantation and stem cell drugs. The biggest difference between them is that the stem cell drug is a product, while allogenic stem cell transplantation is a procedure using the stem cell drug. Moreover, the former is approved as a drug and the latter is approved as a medical device. The details of the main differences are listed in Table 1. 
Table 1. Main differences between stem cell drugs and allogenic stem cell transplantation

\begin{tabular}{|l|l|}
\hline \multicolumn{1}{|c|}{ Stem cell drugs } & \multicolumn{1}{c|}{ Allogenic stem cell therapy } \\
\hline Products of stem cells & Procedures using stem cells \\
\hline Off-the-shelf products & $\begin{array}{l}\text { Using off-the-shelf products or directly use } \\
\text { from donors }\end{array}$ \\
\hline $\begin{array}{l}\text { Produced with large quantity with } \\
\text { consistent quality }\end{array}$ & $\begin{array}{l}\text { Quality differs from batch to } \\
\text { batch }\end{array}$ \\
\hline $\begin{array}{l}\text { Quality of products are controlled } \\
\text { from batch to batch according to } \\
\text { GMP guidelines }\end{array}$ & $\begin{array}{l}\text { Quality differs from batch to } \\
\text { batch depending on donors and } \\
\text { production procedures }\end{array}$ \\
\hline Approved as drugs & Approved as medical devices \\
\hline
\end{tabular}

\section{Stem cell drugs: from personalized to universalized}

Personalized medicine is a medical procedure that separates patients into different groups-with medical decisions, practices, interventions and/or products being tailored to the individual patient based on their predicted response or risk of disease. Stem cells offers a new approach in personalized medicine. Indeed, the definition of "personalized medicine" using stem cells has become a popular term in the last 10 years. To date, there are at least 2 approaches using stem cells in personalized medicine, as presented in Fig. 2.

In this review, we mainly discuss the application of stem cells in stem cell therapeutic transplantation. In stem cell transplantation, autologous stem cells from a patient are used to treat his or her disease. However, the reduction in quality and quantity of stem cells due to aging is a major limitation of this approach. However, after Yamanaka's success with induced pluripotent stem cell production from skin fibroblasts (Takahashi and Yamanaka, 2006), scientists hoped that personalized medicine would lead to greater clinical applications using autologous reprogrammed stem cells (Fig. 3). To date, this approach has faced many limitations and proven to be quite difficult. Even if all the technical difficulties and limitations related to this approach could be solved in the near future, the high price of this procedure would remain a challenge. Indeed, the process of fibroblast isolation, culture and reprogramming for clinical applications is very complex, time-consuming and expensive.

Stem cell drug for universalized medicine has become a new option in stem cell therapy. Stem cell drugs can overcome all the major limitations of autologous stem cells. Particularly, the quality, quantity and price can be controlled. While personalized medicine requires more time for development and is, in some 
ways, a form of medicine for the "future", universalized medicine is more "real" in that the "off-the-shelf", allogeneic stem cell drugs can be used for many patients.

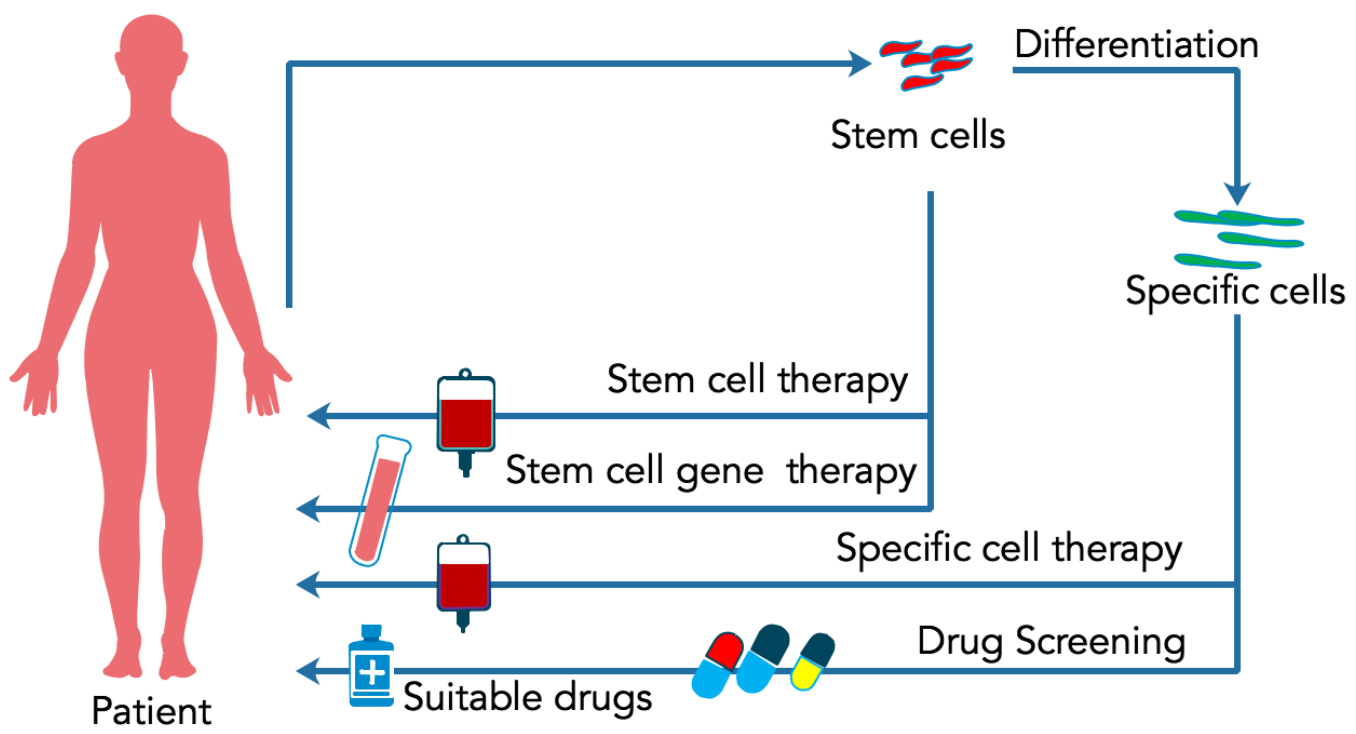

Figure 2. Applications of stem cells in personalized medicine. Stem cells can be used in personalized medicine in various settings, including disease modeling for drug screening or evaluation, stem cell gene therapy for gene correction, and stem cell therapeutic transplantation.

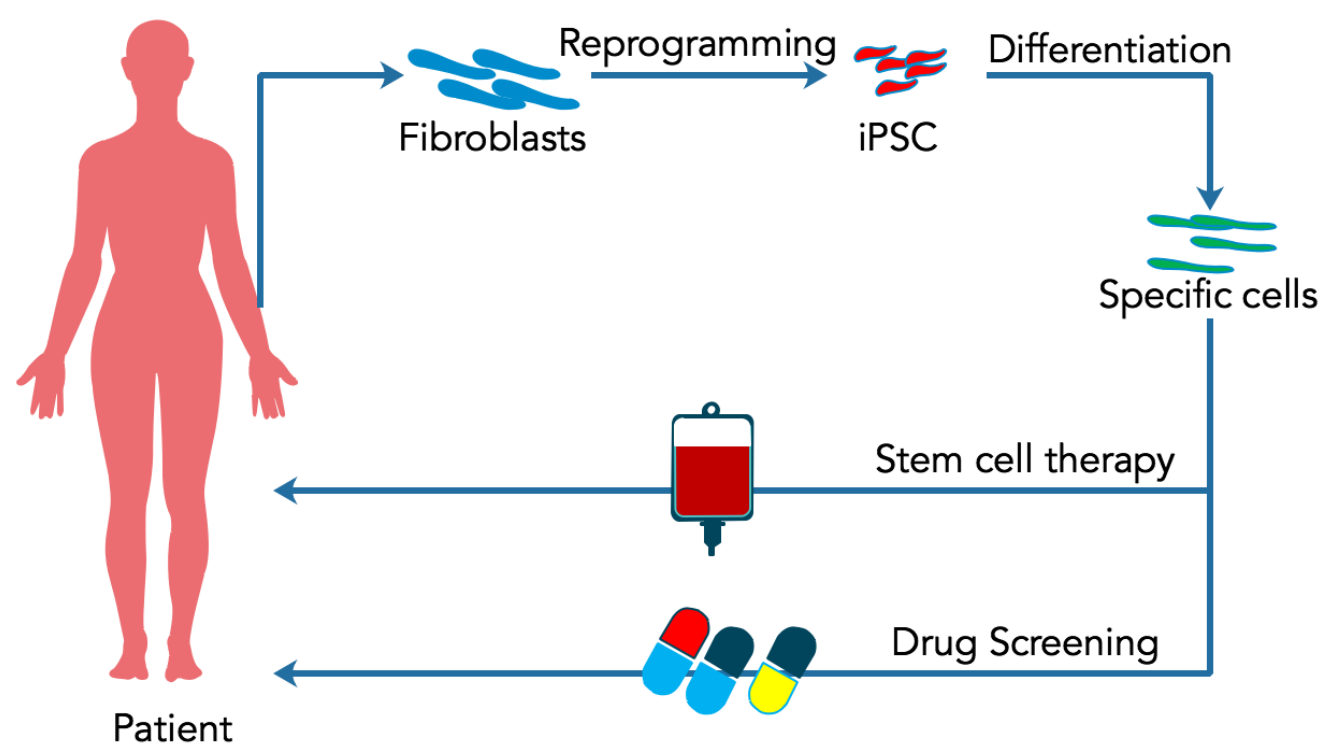

Figure 3. Induced pluripotent stem cells for personalized medicine. Fibroblasts initially isolated from skin are then reprogrammed into induced pluripotent stem cells (iPSCs). The iPSCs are further differentiated into specific cell types before transplantation into patients. 


\section{Stem cell drugs: Drug mechanisms and properties}

Stem cell drugs are mainly produced from HSCs and MSCs (Table 3). However, another kind of stem cell (limbal stem cells) can also be used to produce some products for corneal regeneration. The mechanisms of action of these stem cell drugs are different. While HSC based drugs can regenerate the hematopoietic system in treated patients (via homing and differentiation to functional cells), MSC based drugs typically target the immune system and facilitate healing at injured sites by paracrine or endocrine factors.

\section{Hematopoietic stem cell based drugs}

HSCs are stem cells that can produce blood cells, including white blood cells, red blood cells and platelets, through the process of hematopoiesis. In adults, HSCs are located in the bone marrow and maintain the blood system in the body. The definition of HSC has evolved since the time HSCs were first discovered in 1961 (Till and Mc, 1961). The hematopoietic tissue contains cells with long-term and short-term regeneration capacities as well as committed multipotent, oligopotent and unipotent progenitors. Nowadays, HSCs are found in and mostly isolated from bone marrow, peripheral blood and umbilical cord blood. The first successful bone marrow derived HSC transplantation was performed in 1950s by E. Donnall Thomas at Fred Hutchinson Cancer Research Center (Washington, USA); his work was later recognized with a Nobel Prize in Physiology or Medicine. Thomas infused bone marrow cells to repopulate the bone marrow and produce new blood cells. Furthermore, the first physician to perform a successful human bone marrow transplant for a disease other than cancer was Robert A. Good at the University of Minnesota in 1968. To date, HSCTs have been evaluated in a variety of malignant and non-malignant diseases (Table 2).

The roles of HSCs in both malignant and non-malignant diseases were determined by homing and differentiation of HSCs at bone marrow to form a new hematogenesis system. However, HSCs exert strong immunogenicity on the host immune system. Therefore, HLA matching is critical prior to HSCT. The requirement of HLA matching, however, restricts the development and advancement of HSC based stem cell drugs since there is extremely low HLA matching in the human population. Moreover, it is difficult to induce stem cell proliferation in vitro to increase cell quantity. Although umbilical cord blood seems like a good candidate for an unlimited source of HSCs, it too has challenges which limit its application, including the high cost and time for umbilical cord blood cell collection, enrichment and characterization (e.g. HLA typing). 


\section{Table 2. Indications of HSC transplantation}

\begin{tabular}{|l|l|}
\hline \multicolumn{1}{|c|}{ Malignant } & \multicolumn{1}{c|}{ Non-malignant } \\
\hline Acute myeloid leukemia (AML) & Thalassemia \\
\hline Chronic myeloid leukemia (CML) & Sickle cell anemia \\
\hline Acute lymphoblastic leukemia (ALL) & Aplastic anemia \\
\hline Hodgkin's lymphoma & Fanconi anemia \\
\hline Non-Hodgkin's lymphoma & Immune deficiency syndromes \\
\hline Neuroblastoma & Inborn errors of metabolism \\
\hline Ewing's sarcoma & Autoimmune diseases \\
\hline Multiple myeloma & \\
\hline Myelodysplastic syndromes & \\
\hline Gliomas, other solid tumors & \\
\hline
\end{tabular}

\section{Mesenchymal stem cell based drugs}

Mesenchymal stem cells (MSCs) are the most popular stem cells in the human body. They are present in almost all tissues but the most common sources are bone marrow, adipose tissue, umbilical cord tissue, umbilical cord blood, and placenta. Although the MSCs from the various tissues share common properties, they also exhibit different properties, as suggested by Dominici et al. (2006) (Dominici et al., 2006). Unlike other kinds of stem cells, MSCs are multifunctional; they not only differentiate into multiple cell lineages but they also produce a pool of cytokines and growth factor to execute immune modulation and promote injury healing and tissue regeneration (Caplan and Dennis, 2006; Chen et al., 2008; Hocking and Gibran, 2010; Majumdar et al., 2000; Ren et al., 2008).

MSCs are favorable for clinical applications of stem cell therapy due to their multiple lineage differentiation potential. Stem cells can be differentiated in vitro or in vivo into functional cells which can replace aged or damaged cells. Indeed, some applications of stem cell therapy have entailed differentiating cells from stem cells in vitro and then transplanting them into the recipient as cellular therapy or in combination with biomaterials as tissue engineering therapy. In stem cell transplantation, scientists are also evaluating and trying to promote in vivo differentiation in the microenvironment. Ideally, stem cells can home to injured tissue sites in the body and persist for a long time. Persistence of stem 
cells has been observed in HSC transplantation and, in some cases, in autologous MSC transplantation. Indeed, in MSC transplantation more than 50\% of grafted cells typically die in the recipient from rejection by the immune system and selection in the microenvironment. Autologous transplantation or HLA matching, therefore, are necessary to overcome the kinds of challenges.

Autologous stem cells, however, cannot be produced to mass (industrial) scale and thus stem cell based drugs are highly advantageous. As aforementioned, one important component of stem cell based drugs is the capacity for industrial scale production with similar quality from batch to batch. In most cases, MSCs were used as the source for stem cell based drugs. The two main mechanisms of therapy mediated by stem cell drugs are immune modulation and paracrine/ endocrine effects. Immune modulation is the most common mechanism of commercialized stem cell drugs generated nowadays; about $80 \%$ of stem cell drug products act via immune modulation. This means that the host immune system can be regulated by either indirect or direct interactions between stem cells and host immune cells.

Immune modulation has been observed and documented for mesenchymal stem cells from bone marrow (Bai et al., 2009), adipose tissue (Mello et al., 2015), umbilical cord (Barcia et al., 2015; Cutler et al., 2010), and Wharton's jelly (Prasanna et al., 2010; Weiss et al., 2008). Unlike immune suppression (whereby all immune cells are inhibited in their function), immune modulation is a dynamic process whereby only some cells are affected, i.e. only some cells stimulated. By immune modulation, MSCs can effectively suppress both acute and chronic inflammation. Some stem cell drugs based on MSCs have been approved for use in certain countries and have shown their capability to exert immune modulation; one example is the first stem cell drug (Prochymal) that was evaluated for treatment of GVHD and approved by the Canadian Food and Drug Agency.

The second main mechanism of stem cell drugs relates to the growth factors produced by stem cells. MSCs can produce a pool of growth factors and cytokines which exert biological effects on other cells. MSCs can produce factors that stimulate host stem cells, inhibit apoptosis, and stimulate angiogenesis (Caplan and Dennis, 2006; Chen et al., 2008; Hocking and Gibran, 2010; Majumdar et al., 2000; Ren et al., 2008). Some cytokines exert paracrine effects while others may have endocrine effects.

\section{The future of stem cell drugs}

In recent years, stem cell therapeutics studies has progressed from use of whole stem cells to components derived from stem cells. These components have included stem cell extracts, microvesicles and exosomes, all of which exhibit various biological activities. For example, exosomes from MSCs have functions 
similar to whole MSCs, including repair of tissue damage, suppression of inflammatory responses, and modulation of the immune system. Hu et al. (2016) demonstrated that exosomes from human adipose derived stem cells can accelerate cutaneous wound healing via optimizing the characteristics of fibroblasts (Hu et al., 2016). Similar to MSCs, extra-cellular vesicles (EVs) from MSCs can modulate the immune system (Burrello et al., 2016).

Table 3. Updated stem cell products approved for clinical use

\begin{tabular}{|c|c|c|c|c|}
\hline Trade name & $\begin{array}{c}\text { Stem } \\
\text { cell }\end{array}$ & Company & Approved by & Indications \\
\hline ALLOCORD & $\begin{array}{l}\text { HPC, } \\
\text { Cord } \\
\text { Blood }\end{array}$ & $\begin{array}{l}\text { SSM } \\
\text { Cardinal } \\
\text { Glennon } \\
\text { Children's } \\
\text { Medical } \\
\text { Center }\end{array}$ & 2013 US, FDA & $\begin{array}{l}\text { For use in unrelated donor } \\
\text { hematopoietic progenitor cell } \\
\text { transplantation procedures in } \\
\text { conjunction with an appropriate } \\
\text { preparative regimen for } \\
\text { hematopoietic and immunologic } \\
\text { reconstitution in patients with } \\
\text { disorders affecting the hematopoietic } \\
\text { system that are inherited, acquired, or } \\
\text { result from myeloablative treatment. }\end{array}$ \\
\hline Hemacord & $\begin{array}{l}\text { HPC, } \\
\text { Cord } \\
\text { Blood }\end{array}$ & $\begin{array}{l}\text { New York } \\
\text { Blood } \\
\text { Center, Inc. }\end{array}$ & $\begin{array}{l}2013 \\
\text { US, FDA }\end{array}$ & $\begin{array}{l}\text { For use in unrelated donor } \\
\text { hematopoietic progenitor cell } \\
\text { transplantation procedures in } \\
\text { conjunction with an appropriate } \\
\text { preparative regimen for hematopoietic } \\
\text { and immunologic reconstitution in } \\
\text { patients with disorders affecting the } \\
\text { hematopoietic system that are } \\
\text { inherited, acquired, or result from } \\
\text { myeloablative treatment. }\end{array}$ \\
\hline Ducord & $\begin{array}{l}\text { HPC, } \\
\text { Cord } \\
\text { Blood }\end{array}$ & $\begin{array}{l}\text { Duke } \\
\text { University } \\
\text { School of } \\
\text { Medicine }\end{array}$ & $\begin{array}{l}2012 \\
\text { US, FDA }\end{array}$ & $\begin{array}{l}\text { For use in unrelated donor } \\
\text { hematopoietic progenitor cell } \\
\text { transplantation procedures in } \\
\text { conjunction with an appropriate } \\
\text { preparative regimen for hematopoietic } \\
\text { and immunologic reconstitution in } \\
\text { patients with disorders affecting the } \\
\text { hematopoietic system that are } \\
\text { inherited, acquired, or result from } \\
\text { myeloablative treatment. }\end{array}$ \\
\hline None & $\begin{array}{l}\text { HPC, } \\
\text { Cord } \\
\text { Blood }\end{array}$ & $\begin{array}{l}\text { Clinimmune } \\
\text { Labs, } \\
\text { University of } \\
\text { Colorado } \\
\text { Cord Blood } \\
\text { Bank }\end{array}$ & $\begin{array}{l}2012 \\
\text { US, FDA }\end{array}$ & $\begin{array}{l}\text { For use in unrelated donor } \\
\text { hematopoietic progenitor cell } \\
\text { transplantation procedures in } \\
\text { conjunction with an appropriate } \\
\text { preparative regimen for hematopoietic } \\
\text { and immunologic reconstitution in } \\
\text { patients with disorders affecting the } \\
\text { hematopoietic system that are } \\
\text { inherited, acquired, or result from } \\
\text { myeloablative treatment. }\end{array}$ \\
\hline
\end{tabular}




\begin{tabular}{|c|c|c|c|c|}
\hline None & $\begin{array}{l}\text { HPC, } \\
\text { Cord } \\
\text { Blood }\end{array}$ & $\begin{array}{l}\text { LifeSouth } \\
\text { Community } \\
\text { Blood } \\
\text { Centers, Inc. }\end{array}$ & $\begin{array}{l}2013 \\
\text { US, FDA }\end{array}$ & $\begin{array}{l}\text { For use in unrelated donor } \\
\text { hematopoietic progenitor cell } \\
\text { transplantation procedures in } \\
\text { conjunction with an appropriate } \\
\text { preparative regimen for hematopoietic } \\
\text { and immunologic reconstitution in } \\
\text { patients with disorders affecting the } \\
\text { hematopoietic system that are } \\
\text { inherited, acquired, or result from } \\
\text { myeloablative treatment. }\end{array}$ \\
\hline None & $\begin{array}{l}\text { HPC, } \\
\text { Cord } \\
\text { Blood }\end{array}$ & Bloodworks & $\begin{array}{l}2016 \\
\text { US, FDA }\end{array}$ & $\begin{array}{l}\text { For use in unrelated donor } \\
\text { hematopoietic progenitor cell } \\
\text { transplantation procedures in } \\
\text { conjunction with an appropriate } \\
\text { preparative regimen for hematopoietic } \\
\text { and immunologic reconstitution in } \\
\text { patients with disorders affecting the } \\
\text { hematopoietic system that are } \\
\text { inherited, acquired, or result from } \\
\text { myeloablative treatment. }\end{array}$ \\
\hline Prochymal & MSCs & $\begin{array}{l}\text { Osiris } \\
\text { Therapeutics }\end{array}$ & $\begin{array}{l}2012 \\
\text { Canada }\end{array}$ & $\begin{array}{l}\text { Treatment of graft versus host disease } \\
\text { (GVHD) }\end{array}$ \\
\hline Cartistem & MSCs & $\begin{array}{l}\text { MEDIPOST } \\
\text { Co., Ltd. }\end{array}$ & $\begin{array}{l}2012 \\
\text { Korean FDA }\end{array}$ & $\begin{array}{l}\text { Treatment of knee cartilage defects } \\
\text { caused by degenerative osteoarthritis } \\
\text { or repeated trauma }\end{array}$ \\
\hline $\begin{array}{l}\text { Temcell HS } \\
\text { Inj. }\end{array}$ & MSCs & $\begin{array}{l}\text { JCR } \\
\text { Pharmaceuti } \\
\text { cals Co. Ltd. } \\
\text { (Licensee of } \\
\text { Mesoblast } \\
\text { Limited) }\end{array}$ & $\begin{array}{l}2015 \\
\text { Japan FDA }\end{array}$ & $\begin{array}{l}\text { Treatment of acute graft versus host } \\
\text { disease }(a G V H D) \text { in children and adults }\end{array}$ \\
\hline Stempeucel & MSCs & $\begin{array}{l}\text { Stempeutics } \\
\text { Research } \\
\text { PVT Ltd. }\end{array}$ & $\begin{array}{l}2016 \\
\text { Indian FDA }\end{array}$ & CLI patients due to Buerger's disease \\
\hline
\end{tabular}

Exosomes from stem cells can also affect other systems and organs, such as the cardiovascular system, kidney, liver, nervous system and musculoskeletal system. In the cardiovascular system, exosomes have been suggested as cardioprotective agents (Lai et al., 2010); they have been shown to have proangiogenic effects (Bian et al., 2014) and involvement in reduction of apoptosis and cardiac fibrosis (Feng et al., 2014). Arslan et al. (2013) showed that a single intravenous administration of exosomes was effective in enhancing cardiac function and geometry after myocardial infarction due to bioenergetics re-establishment (increased ATP production), oxidative stress reduction and prosurvival signaling activation (enhanced PI3K/Akt signaling) (Arslan et al., 2013). Recently, Zhang et al. (2016) showed that MSC derived exosomes promoted cardiac stem cell proliferation in vitro (Zhang et al., 2016). In kidney, studies have 
shown that acute kidney injury can be effectively treated with MSC based exosomes (Jiang et al., 2016; Zhou et al., 2013). Moreover, MSC derived exosomes can also be used to treat fibrotic liver disease (Hyun et al., 2015; Li et al., 2013). In some diseases of the musculoskeletal system, exosomes can trigger differentiation of MSCs into osteoblasts (Narayanan et al., 2016) and stimulate skeletal muscle regeneration by enhancing myogenesis and angiogenesis (Nakamura et al., 2015). In the nervous system, MSC derived exosomes have been evaluated in the treatment of neurological and neurodegenerative diseases; they have been shown to enhance angiogenesis and neurogenesis, reduce inflammation and improve spatial learning and sensorimotor function (Kim et al., 2016; Zhang et al., 2015).

Taken together, the aforementioned discoveries suggest the dawn of a new era of stem cell therapy, i.e. stem cell drugs. Here, components (mRNA, protein and peptides) from stem cells, in microvesicles or exosomes, can be effective over whole stem cells. Certainly, the advantages of stem cell drugs include reduction of immunogenicity and easy processing, storage and delivery. Stem cells free drugs may play a potentially important and emerging role in regenerative medicine.

\section{Conclusion}

Stem cell drugs are new members of pharmaceutical medicines that are produced from stem cells. From 2012 to now, more than ten stem cell drugs have been approved in various countries for clinical applications. These products may contain live hematopoietic stem cells or mesenchymal stem cells. With their advantages such as decreased immunogenicity and ease of processing, stem cell drugs have emerged as a promising new platform in the field stem cell therapy around the world. As a new product of pharmaceutical medicine, it is anticipated that stem cell drugs will significantly contribute to both the pharmaceutical and medical industries in the near future. In clinical applications, besides the stem cell drugs which contain live and whole stem cells, new stem cell drugs containing components from stem cells (such as extracts, exosomes and vesicles) are in development and expected to be launched soon.

\section{Lists of abbreviations}

EVs: xtra-cellular vesicles; FDA: Food and Drug Angency; GVHD: graft versus host disease; HLA: Human leukocyte antigen; HPC: Hematopoietic progenitor cells; HSC: Hematopoietic stem cells; HSCT: HSC transplantations. 


\section{References}

1. Ankrum, J.A., Ong, J.F., and Karp, J.M. (2014). Mesenchymal stem cells: immune evasive, not immune privileged. Nature biotechnology 32, 252-260.

2. Appelbaum, F.R. (2007). Hematopoietic-Cell Transplantation at 50. New England Journal of Medicine 357, 1472-1475.

3. Armson, B.A., Allan, D.S., and Casper, R.F. (2015). Umbilical Cord Blood: Counselling, Collection, and Banking. J Obstet Gynaecol Can 37, 832-846.

4. Arslan, F., Lai, R.C., Smeets, M.B., Akeroyd, L., Choo, A., Aguor, E.N., Timmers, L., van Rijen, H.V., Doevendans, P.A., Pasterkamp, G., et al. (2013). Mesenchymal stem cell-derived exosomes increase ATP levels, decrease oxidative stress and activate PI3K/Akt pathway to enhance myocardial viability and prevent adverse remodeling after myocardial ischemia/reperfusion injury. Stem Cell Res 10, 301-312.

5. Bai, L., Lennon, D.P., Eaton, V., Maier, K., Caplan, A.I., Miller, S.D., and Miller, R.H. (2009). Human bone marrow-derived mesenchymal stem cells induce Th2-polarized immune response and promote endogenous repair in animal models of multiple sclerosis. Glia 57, 1192-1203.

6. Barcia, R.N., Santos, J.M., Filipe, M., Teixeira, M., Martins, J.P., Almeida, J., AguaDoce, A., Almeida, S.C., Varela, A., Pohl, S., et al. (2015). What Makes Umbilical Cord Tissue-Derived Mesenchymal Stromal Cells Superior Immunomodulators When Compared to Bone Marrow Derived Mesenchymal Stromal Cells? Stem Cells Int 2015, 583984.

7. Bian, S., Zhang, L., Duan, L., Wang, X., Min, Y., and Yu, H. (2014). Extracellular vesicles derived from human bone marrow mesenchymal stem cells promote angiogenesis in a rat myocardial infarction model. J Mol Med (Berl) 92, 387-397.

8. Burrello, J., Monticone, S., Gai, C., Gomez, Y., Kholia, S., and Camussi, G. (2016). Stem Cell-Derived Extracellular Vesicles and Immune-Modulation. Front Cell Dev Biol 4, 83.

9. Caplan, A.I., and Dennis, J.E. (2006). Mesenchymal stem cells as trophic mediators. Journal of cellular biochemistry 98, 1076-1084.

10. Chen, L., Tredget, E.E., Wu, P.Y., and Wu, Y. (2008). Paracrine factors of mesenchymal stem cells recruit macrophages and endothelial lineage cells and enhance wound healing. PloS one 3, e1886.

11. Cutler, A.J., Limbani, V., Girdlestone, J., and Navarrete, C.V. (2010). Umbilical cordderived mesenchymal stromal cells modulate monocyte function to suppress $T$ cell proliferation. J Immunol 185, 6617-6623.

12. Dominici, M., Le Blanc, K., Mueller, I., Slaper-Cortenbach, I., Marini, F., Krause, D., Deans, R., Keating, A., Prockop, D., and Horwitz, E. (2006). Minimal criteria for defining multipotent mesenchymal stromal cells. The International Society for Cellular Therapy position statement. Cytotherapy 8, 315-317.

13. Feng, Y., Huang, W., Wani, M., Yu, X., and Ashraf, M. (2014). Ischemic preconditioning potentiates the protective effect of stem cells through secretion of exosomes by targeting Mecp2 via miR-22. PLoS One 9, e88685. 
14. Hare, J.M., Traverse, J.H., Henry, T.D., Dib, N., Strumpf, R.K., Schulman, S.P., Gerstenblith, G., DeMaria, A.N., Denktas, A.E., and Gammon, R.S. (2009). A randomized, double-blind, placebo-controlled, dose-escalation study of intravenous adult human mesenchymal stem cells (prochymal) after acute myocardial infarction. Journal of the American College of Cardiology 54, 2277-2286.

15. Hocking, A.M., and Gibran, N.S. (2010). Mesenchymal stem cells: paracrine signaling and differentiation during cutaneous wound repair. Experimental cell research 316, 2213-2219.

16. Hoogduijn, M.J., Popp, F., Verbeek, R., Masoodi, M., Nicolaou, A., Baan, C., and Dahlke, M.-H. (2010). The immunomodulatory properties of mesenchymal stem cells and their use for immunotherapy. International immunopharmacology 10, 1496-1500.

17. Hu, L., Wang, J., Zhou, X., Xiong, Z., Zhao, J., Yu, R., Huang, F., Zhang, H., and Chen, L. (2016). Exosomes derived from human adipose mensenchymal stem cells accelerates cutaneous wound healing via optimizing the characteristics of fibroblasts. Sci Rep 6, 32993.

18. Hyun, J., Wang, S., Kim, J., Kim, G.J., and Jung, Y. (2015). MicroRNA125b-mediated Hedgehog signaling influences liver regeneration by chorionic plate-derived mesenchymal stem cells. Sci Rep 5, 14135.

19. Jiang, Z.Z., Liu, Y.M., Niu, X., Yin, J.Y., Hu, B., Guo, S.C., Fan, Y., Wang, Y., and Wang, N.S. (2016). Exosomes secreted by human urine-derived stem cells could prevent kidney complications from type I diabetes in rats. Stem Cell Res Ther 7, 24.

20. Karussis, D., Karageorgiou, C., Vaknin-Dembinsky, A., Gowda-Kurkalli, B., Gomori, J.M., Kassis, I., Bulte, J.W., Petrou, P., Ben-Hur, T., and Abramsky, O. (2010). Safety and immunological effects of mesenchymal stem cell transplantation in patients with multiple sclerosis and amyotrophic lateral sclerosis. Archives of neurology 67, 1187-1194.

21. Kim, D.K., Nishida, H., An, S.Y., Shetty, A.K., Bartosh, T.J., and Prockop, D.J. (2016). Chromatographically isolated CD63+CD81+ extracellular vesicles from mesenchymal stromal cells rescue cognitive impairments after TBI. Proc Natl Acad Sci U S A 113, 170-175.

22. Kotloff, R.M., Ahya, V.N., and Crawford, S.W. (2004). Pulmonary complications of solid organ and hematopoietic stem cell transplantation. American journal of respiratory and critical care medicine 170, 22-48.

23. Lai, R.C., Arslan, F., Lee, M.M., Sze, N.S., Choo, A., Chen, T.S., Salto-Tellez, M., Timmers, L., Lee, C.N., El Oakley, R.M., et al. (2010). Exosome secreted by MSC reduces myocardial ischemia/reperfusion injury. Stem Cell Res 4, 214-222.

24. Lalu, M.M., Mclntyre, L., Pugliese, C., Fergusson, D., Winston, B.W., Marshall, J.C., Granton, J., and Stewart, D.J. (2012). Safe ty of Cell Therapy with Mesenchymal Stromal Cells (SafeCell): A Systematic Review and Meta-Analysis of Clinical Trials. PloS one 7, e47559.

25. Lee, S.J., Klein, J., Haagenson, M., Baxter-Lowe, L.A., Confer, D.L., Eapen, M., Fernandez-Vina, M., Flomenberg, N., Horowitz, M., and Hurley, C.K. (2007). Highresolution donor-recipient HLA matching contributes to the success of unrelated donor marrow transplantation. Blood 110, 4576-4583. 
26. Li, T., Yan, Y., Wang, B., Qian, H., Zhang, X., Shen, L., Wang, M., Zhou, Y., Zhu, W., Li, W., et al. (2013). Exosomes derived from human umbilical cord mesenchymal stem cells alleviate liver fibrosis. Stem Cells Dev 22, 845-854.

27. Majumdar, M.K., Thiede, M.A., Haynesworth, S.E., Bruder, S.P., and Gerson, S.L. (2000). Human marrow-derived mesenchymal stem cells (MSCs) express hematopoietic cytokines and support long-term hematopoiesis when differentiated toward stromal and osteogenic lineages. Journal of hematotherapy \& stem cell research 9, 841-848.

28. Mello, D.B., Ramos, I.P., Mesquita, F.C., Brasil, G.V., Rocha, N.N., Takiya, C.M., Lima, A.P., Campos de Carvalho, A.C., Goldenberg, R.S., and Carvalho, A.B. (2015). Adipose Tissue-Derived Mesenchymal Stromal Cells Protect Mice Infected with Trypanosoma cruzi from Cardiac Damage through Modulation of Anti-parasite Immunity. PLoS Negl Trop Dis 9, e0003945.

29. Nakamura, Y., Miyaki, S., Ishitobi, H., Matsuyama, S., Nakasa, T., Kamei, N., Akimoto, T., Higashi, Y., and Ochi, M. (2015). Mesenchymal-stem-cell-derived exosomes accelerate skeletal muscle regeneration. FEBS Lett 589, 1257-1265.

30. Narayanan, R., Huang, C.C., and Ravindran, S. (2016). Hijacking the Cellular Mail: Exosome Mediated Differentiation of Mesenchymal Stem Cells. Stem Cells Int 2016, 3808674.

31. P De Miguel, M., Fuentes-Julian, S., Blazquez-Martinez, A., Y Pascual, C., A Aller, M., Arias, J., and Arnalich-Montiel, F. (2012). Immunosuppressive properties of mesenchymal stem cells: advances and applications. Current molecular medicine 12, 574-591.

32. Petersdorf, E.W., Gooley, T.A., Anasetti, C., Martin, P.J., Smith, A.G., Mickelson, E.M., Woolfrey, A.E., and Hansen, J.A. (1998). Optimizing outcome after unrelated marrow transplantation by comprehensive matching of HLA class I and II alleles in the donor and recipient. Blood 92, 3515-3520.

33. Prasanna, S.J., Gopalakrishnan, D., Shankar, S.R., and Vasandan, A.B. (2010). Proinflammatory cytokines, IFNgamma and TNFalpha, influence immune properties of human bone marrow and Wharton jelly mesenchymal stem cells differentially. PLoS One 5, e9016.

34. Rasmusson, I. (2006). Immune modulation by mesenchymal stem cells. Experimental cell research 312, 2169-2179.

35. Ren, G., Zhang, L., Zhao, X., Xu, G., Zhang, Y., Roberts, A.l., Zhao, R.C., and Shi, Y. (2008). Mesenchymal stem cell-mediated immunosuppression occurs via concerted action of chemokines and nitric oxide. Cell stem cell 2, 141-150.

36. Rodenhuis, S., Bontenbal, M., Beex, L.V., Wagstaff, J., Richel, D.J., Nooij, M.A., Voest, E.E., Hupperets, P., van Tinteren, H., and Peterse, H.L. (2003). High-dose chemotherapy with hematopoietic stem-cell rescue for high-risk breast cancer. New England Journal of Medicine 349, 7-16.

37. Sasazuki, T., Juji, T., Morishima, Y., Kinukawa, N., Kashiwabara, H., Inoko, H., Yoshida, T., Kimura, A., Akaza, T., and Kamikawaji, N. (1998). Effect of matching of class I HLA alleles on clinical outcome after transplantation of hematopoietic stem cells from an unrelated donor. New England Journal of Medicine 339, 1177-1185.

38. Takahashi, K., and Yamanaka, S. (2006). Induction of pluripotent stem cells from mouse embryonic and adult fibroblast cultures by defined factors. cell 126, 663-676. 
39. Tallman, M.S., Gray, R., Robert, N.J., LeMaistre, C.F., Osborne, C.K., Vaughan, W.P., Gradishar, W.J., Pisansky, T.M., Fetting, J., and Paietta, E. (2003). Conventional adjuvant chemotherapy with or without high-dose chemotherapy and autologous stem-cell transplantation in high-risk breast cancer. New England Journal of Medicine 349, 17-26.

40. Till, J.E., and Mc, C.E. (1961). A direct measurement of the radiation sensitivity of normal mouse bone marrow cells. Radiat Res 14, 213-222.

41. Wang, Y., Han, Z.-b., Song, Y.-p., and Han, Z.C. (2012). Safety of mesenchymal stem cells for clinical application. Stem cells international 2012.

42. Weiss, M.L., Anderson, C., Medicetty, S., Seshareddy, K.B., Weiss, R.J., VanderWerff, I., Troyer, D., and Mclntosh, K.R. (2008). Immune properties of human umbilical cord Wharton's jelly-derived cells. Stem Cells 26, 2865-2874.

43. Zhang, Y., Chopp, M., Meng, Y., Katakowski, M., Xin, H., Mahmood, A., and Xiong, Y. (2015). Effect of exosomes derived from multipluripotent mesenchymal stromal cells on functional recovery and neurovascular plasticity in rats after traumatic brain injury. J Neurosurg 122, 856-867.

44. Zhang, Z., Yang, J., Yan, W., Li, Y., Shen, Z., and Asahara, T. (2016). Pretreatment of Cardiac Stem Cells With Exosomes Derived From Mesenchymal Stem Cells Enhances Myocardial Repair. J Am Heart Assoc 5.

45. Zhou, Y., Xu, H., Xu, W., Wang, B., Wu, H., Tao, Y., Zhang, B., Wang, M., Mao, F., Yan, Y., et al. (2013). Exosomes released by human umbilical cord mesenchymal stem cells protect against cisplatin-induced renal oxidative stress and apoptosis in vivo and in vitro. Stem Cell Res Ther 4, 34. 